\title{
Udfordringerne i Mali
}

Af André Sonnichsen

Det er en postkolonial hvepserede som de danske specialtropper der skal til Mali i april i år møder, når de ankommer for at styrke den igangværende MINUSMA-indsats (United Nations Multidimensional Integrated Stabilization Mission etableret af FN's Sikkerhedsråd ved Resolution $2100 \mathrm{~d}$. 25.04.2013).

Som en markant pointering af operationens besværlige status blev chef for MINUSMA, Mongi Hamdi, fyret i december 2015. Den tidligere tunesiske udenrigsminister har angiveligt ikke i tilstrækkelig omfang kunnet implementere fredsaftalen af april 2012 og den nationale køreplan af januar 2013, der danner det politiske grundlag for MINUSMA, ej hellere forøget sikkerheden i de nordlige egne, hvor separatister og islamister huserer, ligesom MINUSMA er den fredsbevarende operation med den højeste fatalitetsrate. Hans efterfølger, den tidligere udenrigsminister fra Chad, Mahamat Saleh Annadif, blev officielt udnævnt af FN's generalsekretær Ban Ki-moon allerede den 23. december 2015 med tiltrædelse i februar 2016. Men selvom Annadif har solid erfaring som chef for
AMISOM i Somalia, der ikke er en helt uens situation, konfronteres han med de samme udfordringer som sin forgænger.

Det er netop en klarlægning af disse udfordringer, der står i centrum for nærværende artikel. De kan opdeles i tre kategorier, nemlig operationelle, regionale og principielle. Med udgangspunkt i den danske generalmajor Michael Lollesgårds rolle som styrkechef for MINUSMA drøftes de operationelle udfordringer. De regionale politiske udfordringer i Vestafrika, hvor dynamikkerne trækker i forskellige retninger, belyses via en diskussion af konfliktens parter i det nordlige Mali og i regionale politiske dynamikker. Til sidst drøftes de principielle udfordringer ved indsatsen i Mali, idet MINUSMA hviler solidt på en samtidsfornuft for hvordan freds- og stabiliseringsindsatser bør designes, og hvad deres mål er. Tilsammen skaber disse tre udfordringsniveauer den samlede kontekst for freds- og stabiliseringsopgaven i Mali, der samtidig giver et indblik i den konfliktprægede udvikling i regionen.

\section{Operationelle faktorer}

En række operationelle udfordringer konfronterer MINUSMA. For det før-

André Sonnichsen, ph.d., er politisk analytiker med fokus på udviklings- og sikkerhedspolitik i Afrika. 
ste er der for få kamptropper. FN havde anmodet Danmark om at sende 250 soldater til en kampklar mobil forsyningsenhed, en såkaldt 'Combat Convoy Battalion', der skulle inkludere 20-30 lastvogne. Men da den danske beslutning blev truffet den 30.10.2015 i Udenrigspolitisk Nævn, endte det med, at Danmark forpligtede sig til at sende et Hercules transportfly, op til 30 stabsofficerer og 30 soldater fra Jæger- og Frømandskorpset, der skal af sted fra april til december 2016 .

Baggrunden var, at der havde været splittelse på den danske politiske scene, hvor forsvarsordfører for De Konservative, Rasmus Jarlov, samme dag havde sagt til TV2 News, at "vi mener, at Irak og Syrien er vigtigere i forhold til Mali, der er en lidt perifer konflikt", hvorfor De Konservative altså ikke ønskede at sende danske kamptropper til Mali.Også Dansk Folkeparti var tilbageholdende. DF's forsvarsordfører, Marie Krarup, udtalte samme dag i Politiken, at den danske deltagelse i Mali var 'nice-to-do' og ikke 'need-to-do' fordi der i hendes vurdering ikke er tale om en direkte trussel mod DK.

Uanset om disse to vurderinger er korrekte, har Lollesgaard udtrykt sin frustration over den manglende lydhørhed, ikke kun fra den danske, men også fra andre bidragende regeringer: "Det er ikke fordi, det skorter på internationale bidrag til den fredsbevarende FN-styrke i Mali. Det er bare de forkerte enheder, som bliver sendt af sted". (Information 14.12.2015).

Frustrationen udsprang bl.a. af ønsket om tilstrækkeligt at kunne beskytte forsyningskonvojer, der er sårbare over de store maliske afstande med ringe infrastruktur. Samme aften kunne man på
DR1 Horisont se ‘Ørkengeneralen' Lollesgaard der - konfronteret med et område på størrelse med Frankrig der skal patruljeres - udtalte: "Der havde det altså været lækkert, hvis lige jeg havde lidt flere styrker ude på jorden her og nu. $\mathrm{Nu}$ hutler vi os lidt igennem stadigvæk med alt dette forsyningshalløj her, som tager utrolig mange af vores kræfter". Dagen efter stod det dog lidt mere klart, hvor han beskrev det som sindssygt ærgerligt, at den danske regering ikke vil sende kampsoldater, da det "ville virkelig have været en game changer for os hernede". Desuden, "det er jo alt andet lige mig, der skriver kondolence-brevene og sender kisterne hjem, når vi bliver angrebet". (Information 15.12.2015).

En anden operationel udfordring er, at MINUSMA savner et såkaldt executive policing mandate, nemlig reelle politibeføjelser. I Gao fx, som er et af knudepunkterne i de århundrede gamle transportnetværk, der kobler den sydlige del af Vestafrika tværs over Sahara til Nordafrika og Europa, må FN-personel ikke stoppe eller kontrollere lastbiler.

Selv om de kulturelt rodfæstede transportnetværk åbent bliver brugt til at smugle mennesker, narkotika og våben, og selv om den afledte omsætning af den illegale handel beriger både organiserede kriminelle grupper og selvsamme terrorister, som skal nedkæmpes, må Lollesgaard ikke gribe direkte ind.

Desuden er FN-mandatet ikke direkte terrorbekæmpende, idet der ikke er bemyndigelse til offensiv magtanvendelse, dog retten til selvforsvar, hvis angrebet. Det betyder, at MINUSMA i stort omfang er afhængig af et tæt samarbejde med den franske antiterror indsats i regionen, Operation Barkhane, som har en klar offensiv rolle. 
Af disse grunde er MINUSMAs mandat også beskrevet som 'enormt og nogle gange modsætningsfyldt' af Jean-Hervé Jezequel, senioranalytiker for Sahel ved International Crisis Group. (Reuters World Service, 17.12.2015).

En tredje operationel udfordring er, at det er svært at kende de forskellige grupper fra hinanden, en klassisk problematik i oprørsbekæmpelse nemlig identifikation af fjenden iblandt den almindelige befolkning. Og der er effektive, kampklare fjender tilstede. MINUSMA har flere gange været mål for angreb fra terrorister og har indtil december 2015 mistet 56 soldater, et højt tabstal for en FN-mission set i et komparativt lys.

Ifølge Lollesgaard handler opgaven i det nordlige Mali ikke om at holde stridende parter, der er veldefineret i forhold til hinanden, adskilte. I stedet sker beskyttelse og implementering af fredsaftalen i "et meget komplekst miljø, hvor vi har en blanding af rebeller, oprørere og terroristgrupper, hvor det er svært et erkende den ene gruppe fra den anden”. ('Ørkengeneralen', DR1 Horisont, 14.12.2015). Nogle af disse grupper var med i fredsforhandlingerne og bakker op omkring fredsaftalen, nogle afviser fredsaftalen, og nogle er drevet af bredere islamistiske kræfter i regionen - et enestående svært operationelt miljø for en FN-fredsbevarende mission. Således fremhæver FN, at MINUSMA "is operating in a new geopolitical context and faces threats that have not been encountered before in a peacekeeping context" (UN Security Council, Report of the Secretary-General on the situation in Mali, 2013 p.19).

Opbindingen af konflikten i Mali på netop regionale politiske udviklinger drøftes i kommende afsnit.

\section{Kontekstuelle faktorer}

Problemerne i det nordlige Mali kan ikke forstås uden for et regionalt perspektiv, da mange af aktørerne, som er aktive i Mali, er regionalt forankrede, og mange af de politiske udviklinger i den bredere vestafrikanske region har en direkte indflydelse på den politiske udvikling i Mali. I en vis forstand er det misvisende at tale om 'Mali' som en given størrelse, da de politiske dynamikker på tværs af Malis territoriale grænser er bestemt af fællesskaber og befolkningskløfter, der konkurrerer med og tit er stærkere end de formelle juridiske grænsedragninger foretaget af nationalstater. Det giver sig selv, at i denne kontekst er et forsøg på at lave en national fredsplan og en FN-indsats $i$ et nationalt format en besværlig opgave.

Siden den nordlige opstand i 2012 har konfliktens politiske scene været befolket af følgende hovedaktører:

- Den nationale enhedsregering, etableret med ECOWAS' hjælp 20. August 2012, med Dioncounda Traoré som fungerende statsminister. Herefter med Ibrahim Boubacar Keïta som præsident efter valget $i$ august 2013.

- Tuareg-separatister først organiseret som MNLA (Mouvement National pour la Libération de l'Azawad), som startede oprøret i 2012 i samarbejde med Ansar Eddine og andre islamister (se nedenfor). Nu organiseret som CMA (Coalition of Azawad Movements), efter at bl.a. Ansar Eddine har trukket deres støtte.

- Proregerings-militser eller den såkaldte 14 June Platform Coalition, som er modstandere af CMA, og som hævdes at repræsentere 'genuine interesser' i de nordlige egne. (International Crisis Group, Africa Report No. 226, 2 May 2015). Disse militser kan ses som 
et slags regeringsvenligt 'oprør mod oprøret'.

- Islamister med regionale forgreninger:

- Ansar Eddine, Tuareg-jihadister, ledet af Iyad ag Ghaly

- Ansar Eddines såkaldte Branch for Southern Mali

- MUJAO (Mouvement pour l'unicité et le jihad en Afrique de l'Ouest)

- AQIM (Al-Qaida in the Islamic Maghreb). Stærke i det nordlige Mali, sydlige Algeriet, muligvis i det sydlige Libyen

- Al Mourabitoun, der er ledet af den algeriske jihadist Mokhtar Belmokhtar, og som var en af grupperne, som påtog sig ansvaret for angrebet på Radisson Blu Hotellet i Bamako 20. november 2015. Leder af AQIM, Abu M,usab Abdul Wadud, har annonceret at $\mathrm{Al}$ Mourabitoun har genforenet sig med AQIM og at angrebet på hotellet var dennes 'declaration of unity'. (www.nytimes.com, 4 december 2015)

- Macina Liberation Front, med forbindelse til Ansar Eddine, som også har påberåbt sig ansvar for angrebet på Radisson Blu Hotellet i Bamako 20. november 2015 og en række andre mindre angreb især i den sydlige og centrale del af Mali, hvor de angiveligt rekrutterer iblandt den mindre, etniske gruppe Fulani. Ledes af Hamadoun Kouffa og inkluderer angiveligt tidligere medlemmer af MUJAO.

Hvor de første tre parter er aktive deltagere i fredsprocesserne og har underskrevet både fredsaftalen af den 14. juni 2012, der skabte den nuværende politiske ramme for fredsprocessen som helhed, og de såkaldte honour pacts i Anéfis 16. oktober 2015, der udspecificerede mere detaljeret og på lokalt plan forskellige løsninger på menneskesmugling, magtdeling og stridigheder mellem de lokale parter (ICG, Africa Briefing No.115, 14 december 2015), står den fjerde part, islamisterne, udenfor.

\section{Regionale forhold}

Der er i hvert fald fem regionale forhold der gør, at den samlede politiske konstellation, der inkluderer disse aktører, ikke kan indlemmes i en national politisk ramme:

For det første har spill-over fra konflikten i Libyen fortsat en negativ indvirkning på Mali. Et overskud af våben og trænede kæmpere fra borgerkrigen siver mod syd til mobilisering i regionens øvrige konflikter, herunder den i Mali. Tuareger, der var aktive i konflikten i Libyen, vendte hjem til styrkelse af oprøret i 2012 (DIIS Policy Brief, Regional Security Deterioration after the Collapse of Libya, November 2015).

Libyen er stadig en kilde til islamistisk vækst, indflydelse og ressourcer. For eksempel har IS efter at have skabt et fodfæste i Libyen i 2015 taget ansvaret for både bombeangrebet mod politiskolen $\mathrm{i}$ Zliten 7. januar 2016 og mod oliehavnen Ras Lanuf samme dag. I denne forstand, var Natos bombning af Libyen "en kæmpe fejl, som flere lokale aktører i Afri$\mathrm{ka}$, herunder AU, havde frarådet, fordi man frygtede det sikkerhedsvakuum som Gaddafis afgang ville resultere i". (Thomas Mandrup, lektor ved Forsvarsakademiet, interview 15. december 2015). Det fortsatte anarki og tilstedeværelsen af to forskellige og indtil videre fejlslagne forsøg på national autoritetsdannelse samt et hav af indbyrdes kæmpende militser betyder, at forholdene er ideelle for IS. 
For det andet er forholdet mellem islamister og andre politiske aktører hverken ukompliceret eller entydigt. På den ene side rummer forholdet mellem tuaregerne under CMA og islamisterne mulighed for destabilisering af fredsplanen. I 2012, da oprøret begyndte, samarbejdede Ansar Eddine og tuaregerne under MLNA i fælles front i oprøret mod centralregeringen. Men kort tid efter de store og hurtige territoriale landvindinger i 2012 vendte islamisterne ryggen til MNLA, der blev skubbet ud af de nordlige egne af islamisterne, en udvikling som var direkte anledning til Frankrigs indtræden.

Siden er store dele af norden jo taget tilbage, men kløften mellem tilhængere og modstandere af fredsprocessen er stadig aktuel. For eksempel har leder af Ansar Eddine, Iyad ag Ghaly, kritiseret Anéfis-aftalerne, fordi de befordrer, at centralregeringen kan genvinde kontrollen med det nordlige Mali, og har opfordret til hellig krig mod de franske korsfarere.

Hvis alle ikke-islamistiske parter er samlet om at bekæmpe islamisterne, kan det styrke koalitionen omkring fredsprocessen. En effektiv politisk isolation af islamisterne er klart den logik, der ligger til grund for MINUSMAs tænkning.Men modsat er der også mulighed for, at samarbejdet mellem Tuareg-separatister, der ønsker forøget autonomi, og islamisterne igen kan føre til en fælles front mod $\mathrm{Ba}$ mako, FN og Vesten.

Dette scenarie er bl.a. betinget af islamisternes tiltagende regionale styrke og af omfanget af troværdige og håndgribelige indrømmelser, som Bamako vil give i nord. Selvom CMA på nuværende tidspunkt synes at indlejre sig i fredsprocesserne, er der ikke noget principielt til hinder for, at de igen kan finde fælles fodslag med islamisterne, især hvis sidstnævnte kan mønstres som overbevisende og slagkraftige alliancepartnere.

Hertil skal lægges, at det islamiske civilsamfund er levende og ikke helt entydigt i sin afvisning af islamisterne, ligesom en række islamiske organisationer er aktive på det sociale område. Med andre ord er det ifølge Monique Alexis, strategisk rådgiver for Afrikaprogrammet hos Dansk Institut for Menneskerettigheder, der har arbejdet i Vestafrika i 15 år (interview d. 12.1.2015) ikke en sort-hvid grænse mellem islamisterne og det øvrige samfund i Mali. "De islamiske sociale og religiøse organisationer er stærke især i de områder, hvor staten er svag som i de nordlige og østlige regioner. De er forankrede i den lokale befolkning, de er ofte finansieret af islamisk velgørenhed fra andre lande, de leverer serviceydelser (skoler, klinikker, sanitet m.m.) og er med til at skabe orden. De har en anden tilgang end MINUSMAs dårlige kommunikation, et personale der er fremmedgjort over for græsrodsniveauet og store budgetter i et larmende FN-maskineri" siger Alexis.

På den anden side har islamiske religiøse ledere været uklare i mælet omkring deres position i forhold til islamismen. Præsident for Det Høje Islamiske Råd i Mali, imam Mahmoud Dicko, der er salafist og meget eksplicit vedrørende behovet for et islamisk grundlag for politikken i Mali, nægtede at tage afstand fra islamisternes indtog i 2012. Hans støtte, Mamadou Diamountani, der er formand for valgkommissionen, har i øvrigt anfægtet forfatningen og demokratiet. At en sådan tilgang har genklang hos dele af befolkningen skyldes ifølge Alexis, at "mange i Mali spørger, hvad har demokrati og pluralisme bragt os?" 
For det tredje er en regional sammensmeltning af Sahel og Maghreb som sammenbundet sikkerhedspolitisk område under udvikling. De to regioner har altid været set og analyseret som to relativt afgrænsede regioner med hver deres interne udviklingslogikker. Men nu sker der en sammenklumpning, som betyder, at udviklinger i enkelte lande har relevans langt ud over landets grænser og på tværs af Sahel-Maghreb opdelingen (DIIS Policy Brief, Regional Security Deterioration after the Collapse of Libya, November 2015). For eksempel matcher Algeriets forsøg på at skubbe AQIM mod syd ind i Sahara Malis forsøg på at skubbe islamisterne mod nord.

For det fjerde synes konkurrencen mellem al-Qaeda og IS at blive optrappet $\mathrm{i}$ regionen som resultat af den regionale sammenbinding (DIIS Comment, $A l$ Qaeda affiliates - not Islamic State - behind Bamako hotel attack. 30. november 2015). Selvom IS generelt vurderes som værende svag i Mali, er dette i dag mindre tilfældet i regionen end tidligere, hvor ikke blot Libyen er skueplads for en tydelig styrkelse af IS, men hvor også Boko Haram, der står meget klart i deres støtte til IS, huserer i det nordlige Nigeria og i områderne ved Chadsøen i Niger og Chad.

Hvis Mali kan få status som endnu en højtprofileret front imod korsfarerne, kan dette tiltrække IS-ekspansion i området. Desuden er loyaliteten hos de mindre, regionale jihadistiske grupper i Sahelregionen angiveligt ret labil, og der skal ikke megen fantasi til at forestille sig, at mange af disse vil følge 'den stærke' snarere end 'den rigtige'. En afklaring af konkurrencen mellem al-Qaeda og IS og en regional konsolidering af kludetæppet af islamistiske grupperinger ville klart forværre sikkerhedssituationen. Ser man for sig i de overlappende og gennemkrydsede regioner, hvor nationalgrænserne udgør en ringe forhindring, en kritisk masse, der kan medføre, at endnu et skud på IS træet bliver erklæret?

\section{Indsatsformat ctr. trusselsformat}

Den femte og sidste faktor i rækken af kontekstuelle faktorer er spørgsmålet, om hvorvidt de regionale samarbejder, der er iværksat af regionale og internationale aktører, er den rigtige respons? Der kan være grund til at spørge, om indsatsformatet matcher trusselsformatet?

Franskmændenes hurtige militære reaktion i form af Operation Sérval i starten af 2013 efter anmodningen om hjælp fra Mali var på overfladen en succesrig tilbagevisning af islamisternes fremmarch mod Bamako, der dog er afløst af en oprørsbekæmpelse. På samme ret hurtige måde etablerede man allerede i 2012 på foranledning af ECOWAS den politisk ramme for en videre politisk proces mellem parterne, der førte til oprettelsen af UNOM (United Nations Missions in Mali) og AFISMA (International Support Mission in Mali), som i 2013 blev overdraget til FN i form at MINUSMA.

Af denne grund er "denne stabiliseringsindsats i udgangspunktet som AU gerne vil have det, fordi den er baseret på en AU-mission, der siden blev transformeret om til en FN-operation. Der er grundlæggende tale om en afrikansk mission, hvilket giver et stort bidrag til dens politiske legitimitet". (Thomas Mandrup, lektor ved Forsvarsakademiet, interview 15. december 2015). Med andre ord man har på nationalt plan og helt ifølge stabiliseringstænkning foretaget de nødvendige politiske og militære skridt. Men franskmændenes udvidelse i 2013 
af Operation Sérval til Operation Barkhane, der omfatter fem lande (Chad, Niger, Mali, Burkina Faso og Mauritania), er en erkendelse af det regionale format af problemerne. Militært set er der også andre eksempler på en regional tilgang for eksempel amerikanernes Operation Flintlocks årlige antiterror øvelser siden 2005, der på tværs af regionen befordrer landenes samarbejde mod terrornetværk (Reuters World Service, 16.02.2015).

Her ser vi faktisk en inddragelse af lande fra Maghreb og Sahel nemlig Algeriet, Burkina Faso, Cameroun, Mali, Mauritania, Niger, Nigeria, Senegal og Tunesien. Amerikanerne er længst fremme med integrerede regionale militærindsatser, der angiveligt i fremtiden vil tage form af et netværk af nye mini-baser på tværs af hele Sahel, fra Vestafrika til Afrikas Horn. Målet er at bygge en vedvarende infrastruktur til dronedrift og til specialetroppeoperationer, en løsning der er billigere og mindre politisk anstødelig end store amerikanske militærbaser for de afrikanske lande, der lægger jord til landingsbanerne. Der har været droner placeret i Niger siden 2013.

Problemet med manglende match mellem trusselsformat og indsatsformat har man set før både i Afghanistan, hvor Taleban har kunnet beskytte sig i baser i Pakistan, som er uden for ISAFs rækkevidde, og aktuelt i Syrien, hvor IS spreder sig over nationale jurisdiktioner, der gør effektiv handling besværlig. På samme måde trodser de aktuelle politiske konfliktlinjer i Mali internationale grænser og skaber endnu et eksempel på et manglende match mellem indsatsformatet og trusselsformatet. På samme måde som Islamisk Stat har et geografisk format, der aftvinger en suspendering af almindelige analytisk tænkning, kan isla- misternes netværk i Vestafrika vanskeligt håndteres nationalt eller ifølge nationale institutioner og nationale logikker. Disse netværk er forankrede i politiske fællesskaber, der er tværgående og slagkraftige. Med andre ord endnu et eksempel på samtidens globaliserede trusler, hvor nationalstaten kommer til kort.

Naturligvis er der en række regionale politiske indsatser, herunder Sahel G5 gruppen, der består af Mauretanien, Mail, Niger, Chad og Burkina Faso, med en udviklingspolitisk dagsorden bl.a. finansieret af Verdensbanken, EU, og African Development Bank, og som er EU's regionale satsning på udviklings- og sikkerhedspolitik. Godt begyndt, men man ekskluderer dermed en af områdets centrale spillere, Algeriet, som foragter især fransk indblanding i regionen, og desuden genetablerer man Sahel-Maghreb opdelingen.

Algeriet og andre Maghreb-lande er til gengæld med i Obamas Global Counter-Terrorist Forum etableret i 2011, der inkluderer en Sahel Capacity Building Working Group, som mest er vejledende og til dels forskningsorienteret, men som ikke er tænkt som et effektivt maskineri for diplomatiske løsninger.

Og ECOWAS og Den Afrikanske Union har indtil videre holdt sig til de nationale logikker, som de selv er affødt af.

\section{Principielle faktorer}

Tanken om at det nordlige Mali kan blive et terroristhelle, er helt i tråd med den sikkerhedspolitiske tænkning i perioden efter den kolde krig og især efter 9/11, som påpeger, at såkaldte 'ungoverned spaces' er en af samtidens alvorligste sikkerhedstrusler. Argumentet er, at fraværet af en legitim og funktionsdygtig politisk autoritet, der kan skabe rammerne for levering 
Hvis en demokratisk retsstat mest ligner manifestationen af en foragtet vestlig livsform, så savner vi effektive redskaber til et modsvar. Vores rettighedsbaserede politik er ikke designet til at imødegå dette fænomen, ligesom vores politik til opbygning af demokratiske retsstater helt åbenlyst møder en grænse ikke kun i Mali, men også i andre lignende sammenhænge.

af basale sociale ydelser, orden og sikkerhed osv., muliggør opblomstringen af alternative ordensformer, der kan være fjendtligt indstillet over for den pågældende nationalstat og over for Vesten.

Den analyse ligger til grund for den generelle tilgang til stabilisering og udvikling af skrøbelige stater, som ved brug af en kombination af forskellige udviklingsog statsbygningsredskaber skal befordre skabelsen af nationale demokratiske retsstater. Denne grundlæggende model går igen $\mathrm{i}$ et bredt udvalg af bilaterale og multilaterale politikker, der ser demokratipromovering som god, sammentænkt sikkerhedspolitik. Helt i tråd hermed lægger FN-resolutionen, der etablerede MINUSMA, vægt på "Stressing the need to work expeditiously toward the restoration of democratic governance and constitutional order, including through the holding of free, fair, transparent and inclusive presidential and legislative elections" og "Encouraging the international community to provide broad support to resolve the crisis in Mali through coordinated actions for immediate and long-term needs, encompassing security, governance, development and humanitarian issues". (UN Security Council, Resolution 2100, 25 April 2013, p. 1 and p. 6).

Men denne tilgang er der ikke enighed om blandt konfliktens parter. Lederen af Ansar Eddine, den islamistiske tuareg Iyad ag Ghaly, er meget illustrativ. I ‘Ørkengeneralen' hører vi, hvordan Ghaly, som tidligere var engageret $i$ at organisere de internationalt berømte musikfestivaler i Timbuktu, over en årrække bli- ver mere og mere kritisk over for vestlig indflydelse og kultur, mere tiltrukket af et brud med det bestående og af islamismen, indtil han i dag er en af konfliktens mest efterlyste oprørere, som franske tropper indtil videre uden held har prøvet at dræbe. Hans tidligere ven, den maliske musikker Manny Ansar, undrer sig: "Jeg spurgte hver eneste dag, hvad det var, der skete med min ven Iyad? Han kunne godt lide musik, han er et godt og ordentligt menneske. Han har aldrig løjet over for mig, han behandler folk med respekt. Hvad skete der med ham?" Denne hengivelse til islamismen er et velkendt samtidsfænomen.

Hvad nu hvis det netop har været forsøgene over de sidste 20 år på at forvandle svage stater til demokratiske retsstater, som har skabt problemerne? Hvad nu hvis Vestens rettighedsbaserede, angiveligt inklusive tilgang, hvis indiskutable præmis er, at den enkelte ser en demokratisk retsstat som en i princippet ønskværdig politisk målsætning, er fejlplaceret og leder os til en forkert diagnosticering af problemet? Hvis en demokratisk retsstat mest ligner manifestationen af en foragtet vestlig livsform, så savner vi effektive redskaber til et modsvar. Vores rettighedsbaserede politik er ikke designet til at imødegå dette fænomen, ligesom vores politik til opbygning af demokratiske retsstater helt åbenlyst møder en grænse ikke kun i Mali, men også $i$ andre lignende sammenhænge.

På samme måde er vores samfundsvidenskabelige forklaringsmodeller om, at radikalisering og ekstremisme skyl- 
des marginalisering, hårdt pressede i lyset af islamismens tiltrækningskraft og den reelle hengivelse til alternative ordens- og livsformer. Vi forstår ganske enkelt ikke de processer, der medfører, at folk vælger en anden livsform end den, som den vestlige model foreskriver. Heri ligger den førte politiks største erkendelsesmæssige og politiske udfordring. Det nemmeste er at lade konstatering af en fundamental forskellighed være slutpunktet for vores analyser og sætte hårdt mod hårdt. Mere potentiale ligger der $\mathrm{i}$ at lade fundamental forskellighed være udgangspunktet for en produktiv gentænkning.

\section{Konklusion}

Mali-indsatsen er trods dens enestående og kontekstuelle spidsfindigheder en eksemplarisk postkolonial stabiliseringsøvelse.

'Postkolonial' fordi Mali udviser alle de fællestræk, som vi allerede kender fra andre postkoloniale lande, nemlig diverse kollektive identiteter, der skaber et fragmenteret socialt grundlag for ordensdan- nelse: Det nationale fællesskab er kun på opsplittede og betingede måder loyalt over for de institutionelle overbygninger, der skal regere over det, og som i øvrigt savner kapacitet og legitimitet. Tilsætter man hertil et regionalt forankret, internt opsplittet og tiltagende islamistisk oprør med helt andre drømme end en demokratisk, vestligt orienteret retsstat i Mali, har man sagen i en nøddeskal.

Eksemplarisk 'stabiliseringsøvelse' fordi MINUSMAs konkrete indsatser og overordnede design udspringer af et demokratipromoveringsparadigme, som Vesten og det internationale samfund har anvendt i perioden efter den kolde krig. I skrivende stund ser det ud til, at fredsog stabiliseringsindsatser fortsat kommer til at have en fremtrædende rolle i Taksøe-Jensens udspil til en kommende sammentænkt dansk udenrigspolitik. Ikke mindst af denne grund bør vi tænke klart og holde øje med, hvordan tingene udmønter sig i Mali. 